\title{
Water-use efficiency in Flaveria species under drought-stress conditions
}

\author{
M.C. DIAS ${ }^{*,+}$ and W. BRÜGGEMANN ${ }^{* * * * *}$ \\ Centre for Environmental and Marine Studies (CESAM), Department of Biology, University of Aveiro, \\ 3810-193 Aveiro, Portugal \\ Department of Ecology, Evolution and Diversity, J.W. Goethe University, POB 111932, \\ D-60054 Frankfurt am Main, Germany ${ }^{* *}$ \\ Biodiversity and Climate Research Centre, Senckenberganlage 25, \\ D-60325 Frankfurt am Main, Germany ${ }^{* * *}$
}

\begin{abstract}
Environmental conditions that promote photorespiration are considered to be a major driving force for the evolution of $\mathrm{C}_{4}$ species from $\mathrm{C}_{3}$ ancestors. The genus Flaveria contains $\mathrm{C}_{3}$ and $\mathrm{C}_{4}$ species as well as a variety of intermediate species. In this study, we compare the water-use efficiency of intermediate Flaveria species to that of $\mathrm{C}_{3}$ and $\mathrm{C}_{4}$ species. The results indicate that under both well-watered and a drought-stress condition, $\mathrm{C}_{3}-\mathrm{C}_{4}$ and $\mathrm{C}_{4}$-like intermediacy in Flaveria species improve water-use efficiency as compared to $\mathrm{C}_{3}$ species.
\end{abstract}

Additional key words: drought stress; Flaveria; intermediate species; water-use efficiency.

The genus Flaveria (Asteraceae) includes both $\mathrm{C}_{3}$ and $\mathrm{C}_{4}$ species (NADP-malic enzyme type) as well as a number of intermediate species $\left(\mathrm{C}_{3}-\mathrm{C}_{4}\right.$ and $\mathrm{C}_{4}$-like $)$ that represent stages in the evolutionary transition from $\mathrm{C}_{3}$ to $\mathrm{C}_{4}$ photosynthesis (Monson and Rawsthorne 2002, McKown et al. 2005). $\mathrm{C}_{3}$ photosynthesis is the ancestral condition, and multiple origins of intermediate and $\mathrm{C}_{4}$ photosynthesis are present in the genus (Kocacinar et al. 2008). Therefore, this genus has been widely used as a model for studying the physiology and molecular biology of the $\mathrm{C}_{4}$ plant evolution (Sage 2004, Westhoff and Gowik 2004, McKown et al. 2005).

In Flaveria, intermediate species have been subdivided into $\mathrm{C}_{3}-\mathrm{C}_{4}$ and $\mathrm{C}_{4}$-like species. Compared to $\mathrm{C}_{3}$ plants, all intermediate species exhibit a reduced level of photorespiration and a more differentiated Kranz-like leaf anatomy. In the $\mathrm{C}_{3}-\mathrm{C}_{4}$ intermediates, $\mathrm{C}_{4}$ biochemistry is present in some species with an assimilation of $\mathrm{CO}_{2}$ through the $\mathrm{C}_{4}$ cycle ranging from $20 \%$ to $60 \%$ (Monson 1999). However, the $\mathrm{CO}_{2}$ assimilation in these intermediates occurs mainly in the mesophyll cells and the reduction of photorespiration is primarily due to the recycling of the photorespired $\mathrm{CO}_{2}$ by glycine decarboxylase (Monson and Rawsthorne 2002). In the so-called $\mathrm{C}_{4}$-like Flaveria species, the $\mathrm{C}_{4}$-like biochemistry results in $70-90 \% \mathrm{CO}_{2}$ assimilation through PEPCase, with a concomitant enhancement of the $\mathrm{CO}_{2}$ level in the bundle sheath cells (Monson and Rawsthorne 2002). The reduction of $\mathrm{O}_{2}$ sensitivity of photosynthesis and the increase of photosynthetic rates in the $\mathrm{C}_{4}$-like species are mainly due to the high degree of development of the $\mathrm{C}_{4}$ syndrome (Monson and Rawsthorne 2002). Unlike $\mathrm{C}_{4}$ species, the differential distribution of Rubisco and PEPCase between mesophyll and bundle sheath cells is not complete in the $\mathrm{C}_{4}$-like Flaveria species (Reed and Chollet 1985).

Environmental conditions that enhance photorespiration, such as low atmospheric $\mathrm{CO}_{2}$ concentrations, high temperatures, and aridity, are considered to be a major driving force to promote the evolution of the $\mathrm{C}_{4}$ metabolic pathway (Sage 2004). The adaptation to constant and temporary drought conditions through a more

Received 3 March 2010, accepted 11 June 2010.

${ }^{+}$Corresponding author; tel.: +351 234370 200, fax: +351234370 985; e-mail: celeste.dias@ua.pt

Abbreviations: DS - drought stress; PEPCase - phosphoenolpyruvate carboxylase; Rubisco - ribulose-1,5-bisphosphate carboxylase/ oxygenase; WUE - water-use efficiency.

Acknowledgement: This work was supported by Portuguese Foundation for Science and Technology (FCT): grant reference SFRH/BPD/41700/2007. 
economical use of available water is appointed to be an important impulse for the evolution of $\mathrm{C}_{4}$ species from the $\mathrm{C}_{3}$ ancestors (Apel et al. 1994). In the genus Flaveria, data from biogeographic distribution and ecological preferences of the species supports the hypothesis that the multiple origins of the $\mathrm{C}_{4}$ photosynthesis were the result of selection pressures for survival in hot, arid, or saline conditions (McKown et al. 2005, Kutschera and Niklas 2007). Additional knowledge of the water-use efficiency (WUE) in intermediate Flaveria species under nonoptimal environmental conditions is needed to better understand how environmental conditions drive the evolution of the $\mathrm{C}_{4}$ photosynthetic cycle.

In this study, we compare WUE in two intermediate species that have different degrees of $\mathrm{C}_{4}$-syndrome $\left(\mathrm{C}_{3}-\right.$ $\mathrm{C}_{4}$ and a $\mathrm{C}_{4}$-like Flaveria species) with the $\mathrm{C}_{3}$ and $\mathrm{C}_{4}$ Flaveria species under well-watered growth conditions (control) as well as under water-limiting conditions. Our results give more information on the advantages of the intermediate species under stress environmental conditions and bring more insight on the role of the WUE in the evolution of the $\mathrm{C}_{4}$ pathway in this genus.

Flaveria species used in this experiment were kindly provided by Prof. Dr. Westhoff, University of Düsseldorf, Germany. All genotypes were propagated and cultivated in glasshouses of the Botanical Garden from the University of Frankfurt. Plants of $F$. trinervia (NADP-malic enzyme type $\mathrm{C}_{4}$ ) were grown from seeds and $F$. pringlei $\left(\mathrm{C}_{3}\right), F$. floridana $\left(\mathrm{C}_{3}-\mathrm{C}_{4}\right)$, and $F$. brownii $\left(\mathrm{C}_{4}\right.$-like $)$ from cuttings in a mixture of $50 \%$ sand and $50 \%$ peat. After 2-3 weeks, when the cuttings presented roots, the plants were transferred to $1-\mathrm{kg}$ plastic trays $(11 \times 11 \times$ $12 \mathrm{~cm}^{3}$ ) containing a soil mixture of $25 \%$ sand, $25 \%$ organic matter, and $50 \%$ peat. Plants were grown in a climate chamber at $23^{\circ} \mathrm{C}, 40-60 \%$ relative humidity, $14 / 10 \mathrm{~h}$ day/night rhythm with a photosynthetic photon flux density (PPFD) of $400 \mu \mathrm{mol} \mathrm{m} \mathrm{m}^{-2} \mathrm{~s}^{-1}$ provided by Osram 1,000 W lamps and received water daily. Threeto four-week-old plants were exposed to drought stress (DS) by receiving only so much water every evening to ensure a water content corresponding to $30 \%$ field capacity overnight, corresponding to water potential of approx. -1.6 MPa (Scheffer and Schachtschnabel 2002, Beyel and Brüggemann 2005). After 3-4 days, plants reached a water potential between -1.0 and $-1.8 \mathrm{MPa}$ during the DS treatment, which persisted for three days further. For comparison reasons, other plants with the same age were maintained under control conditions at a field water capacity.

Whole-plant water potentials were measured with a SKPM 1400 pressure chamber (SKYE Instruments, Powys, Wales, UK) on abscised stems just above the soil surface, according to Scholander (1965). Osmotic potential of leaf pressure saps were determined by freezing point depression with an Osmomat 030 (Gonotec, Berlin, Germany) according to Walter and Kreeb (1970). Turgor (pressure potential) was estimated by the difference between water potential and osmotic potential.

In situ determinations of photosynthetic rate and transpiration rate at saturating PPFD $[1,000 \mu \mathrm{mol}$ (photon) $\mathrm{m}^{-2} \mathrm{~s}^{-1}$ for $F$. pringlei or $2,000 \mu \mathrm{mol}\left(\right.$ photon) $\mathrm{m}^{-2} \mathrm{~s}^{-1}$ for

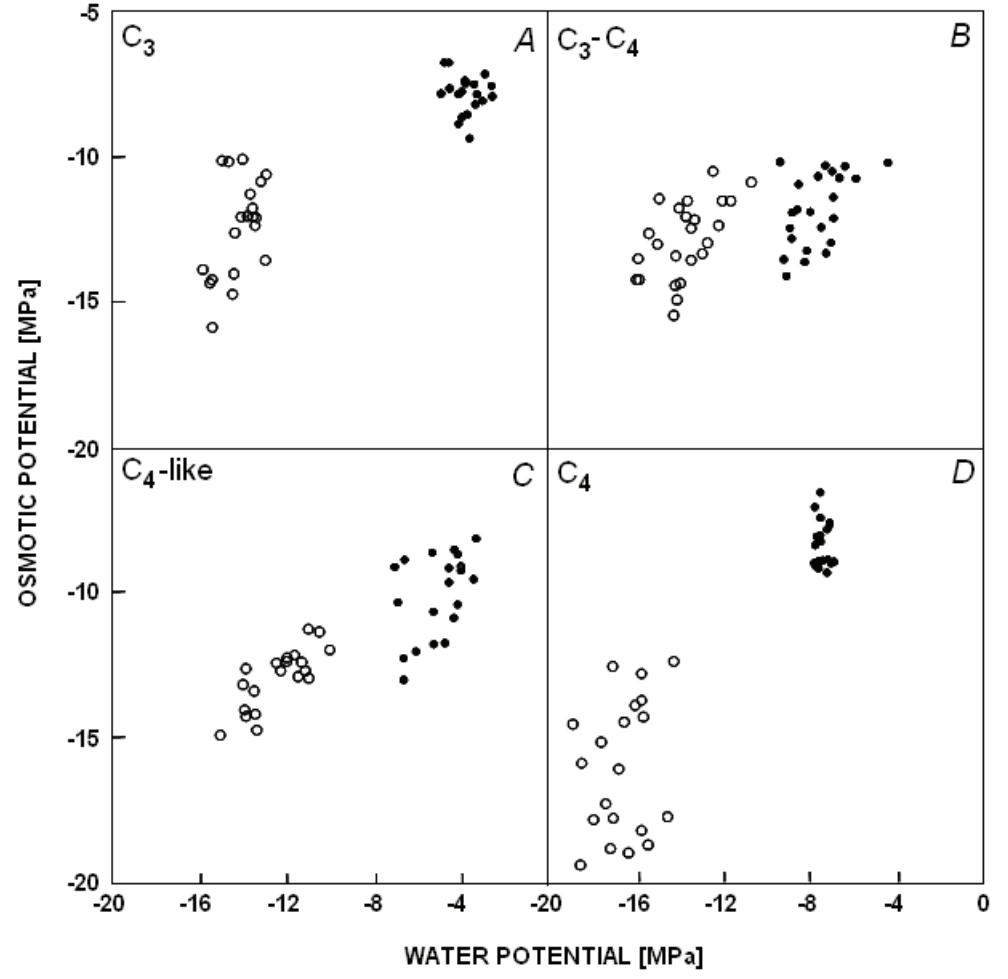

Fig. 1. Response of osmotic potential to decreasing plant water potential in control (filled circles) and drought stressed plants (open circles) of $F$. pringlei $(A), F$. floridana $(B), F$. brownii $(C)$ and $F$. trinervia (D) $(n=20-24)$. 


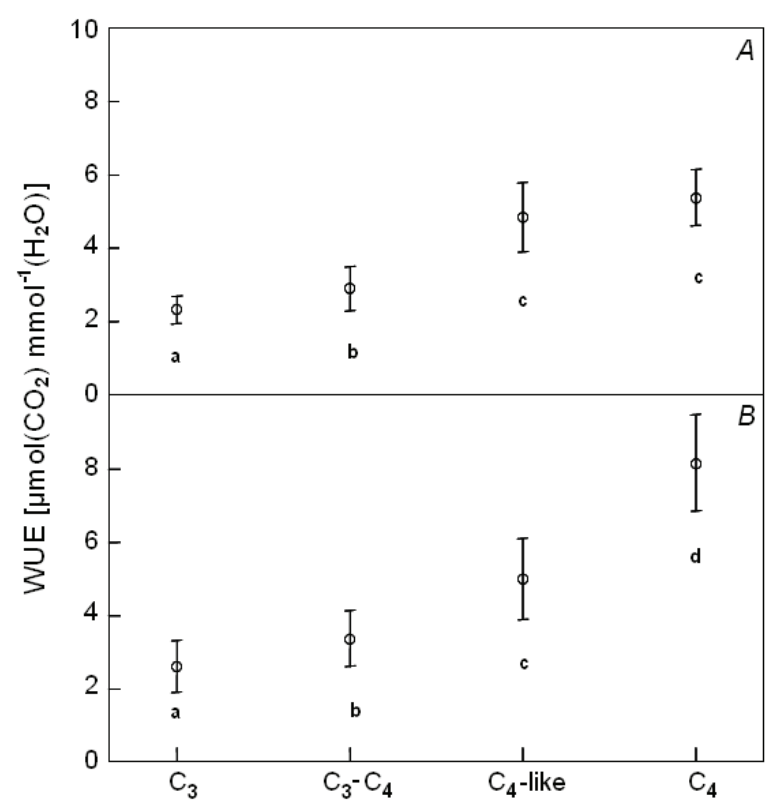

Fig. 2. Water-use efficiency (WUE) in control $(A)$ and droughtstressed plants $(B)$ of Flaveria pringlei $\left(\mathrm{C}_{3}\right), F$. floridana $\left(\mathrm{C}_{3}-\mathrm{C}_{4}\right), F$. brownii $\left(\mathrm{C}_{4}\right.$-like $)$ and $F$. trinervia $\left(\mathrm{C}_{4}\right)$. Values are means \pm SD $(n=18-21)$. Different letters indicate statistically significant differences.

the other species] were measured with a $L I-6200$ infrared gas analyzer (LiCor, Lincoln, NE, USA) under growthchamber conditions $\left[370 \mu \mathrm{mol}\left(\mathrm{CO}_{2}\right) \mathrm{mol}^{-1}\right]$. The relative humidity of air entering the cuvette was set at $60 \%$ and the cuvette temperature was $23^{\circ} \mathrm{C}$. The flow rate of air through the sample chamber was set at 200-300 $\mathrm{mmol} \mathrm{s}^{-1}$ Plants were illuminated during 15-20 $\mathrm{min}$ before the photosynthesis measurements. WUE was calculated as the ratio of the photosynthetic rate $\left[\mu \mathrm{mol}\left(\mathrm{CO}_{2}\right) \mathrm{m}^{-2} \mathrm{~s}^{-1}\right]$ and transpiration rate $\left[\mathrm{mmol}\left(\mathrm{H}_{2} \mathrm{O}\right) \mathrm{m}^{-2} \mathrm{~s}^{-1}\right]$ for each species in control and DS conditions. Measurements were always performed in the youngest fully developed leaf. The gas analyzer was calibrated every day according to the manufacturer's recommendations.

The quantitative analysis is based on individual measurements of 20-24 plants for water potential and osmotic potential, and 18-21 plants for photosynthetic rate and transpiration rate.

For each group of control and DS plants, we analysed the results in terms of WUE with respect to different photosynthetic pathways by using one-way analysis of variance $(A N O V A)$. Pairwise comparisons between means were evaluated by Tukey's Multiple Comparison Test at a significant level 0.05 . The analysis was performed with SigmaStat for Windows, version 3.1.

In order to quantify the degree of DS in F. pringlei, $F$. floridana, $F$. brownii, and $F$. trinervia, water potential and osmotic potential were measured in control and DS plants. Fig. 1 shows the response of osmotic potential to decreasing plant water potential in Flaveria species exposed to DS. In the $\mathrm{C}_{3}$ and $\mathrm{C}_{4}$ species, the strong decline of the water potential from control to DS was also followed by a high decrease of the osmotic potential (Fig. 1A,D). However, in both intermediate species, despite the high decrease in water potential, osmotic potential decreased only slightly from control to DS plants (Fig. 1B,C). Drought stress resulted in a decrease of turgor in the $\mathrm{C}_{4}$ and intermediate species. In the $\mathrm{C}_{3}$ plant, turgor potential was completely lost.

Fig. 2 reports the WUE in control and DS Flaveria species. According to our ANOVA analysis, the calculated WUE under control conditions increased significantly from the $\mathrm{C}_{3}$ species to the intermediates and $\mathrm{C}_{4}$ species (Fig. 2A). However, the mean values of WUE in the $\mathrm{C}_{4}$ and $\mathrm{C}_{4}$-like species were not statistically different [5.36 \pm 0.74 and $4.84 \pm 0.94 \mu \mathrm{mol}\left(\mathrm{CO}_{2}\right) \operatorname{mmol}\left(\mathrm{H}_{2} \mathrm{O}\right)^{-1}$, respectively]. The $\mathrm{C}_{3}$ species presented the lowest WUE whereas the $\mathrm{C}_{4}$ and $\mathrm{C}_{4}$-like species presented the highest WUE mean under well-watered conditions. Under DS conditions, the $\mathrm{C}_{4}$ plant achieved the highest WUE $[8.15 \pm 1.30$ $\left.\mu \operatorname{mol}\left(\mathrm{CO}_{2}\right) \operatorname{mmol}\left(\mathrm{H}_{2} \mathrm{O}\right)^{-1}\right]$ and the $\mathrm{C}_{3}$ plant presented the lowest WUE mean $\left[2.61 \pm 0.68 \mu \operatorname{mol}\left(\mathrm{CO}_{2}\right) \operatorname{mmol}\left(\mathrm{H}_{2} \mathrm{O}\right)^{-1}\right]$. The WUE mean in intermediate species was significantly higher than that of the $\mathrm{C}_{3}$ species under DS (Fig. $2 B$ ).

The results obtained in this study for the four Flaveria species varied markedly in their sensitivity towards DS. Under the same DS conditions, water potential declined in all species and turgor potential was completely lost in the $\mathrm{C}_{3}$ species. Furthermore, the results show that $\mathrm{C}_{3}-\mathrm{C}_{4}$ and $\mathrm{C}_{4}$-like intermediacy in Flaveria species brings advantages, namely higher WUE, as compared to the $\mathrm{C}_{3}$ species under the same environmental conditions.

In an earlier study (Dias and Brüggemann 2007), it has been shown that stomatal conductance decreased the most strongly in the $\mathrm{C}_{3}$ species $F$. pringlei under DS, leading to complete closure of the stomata and also to complete loss of turgor. In the other three species, a moderate to strong decline of stomatal conductance had been observed. An increase in the stomatal response to light and $\mathrm{CO}_{2}$ enhances the ability of the stomatal response to environmental variations at relative low stomatal conductances and the acquisition of this trait occurred at the end of the evolutionary $\mathrm{C}_{4}$-cycle process (Sage 2004). F. floridana exhibits a stronger stomatal response to light and $\mathrm{CO}_{2}$ than that of the $\mathrm{C}_{3}$ Flaveria species (e.g. F. pringlei and F. robusta) and other $\mathrm{C}_{3}-\mathrm{C}_{4}$ Flaveria species (e.g. F. chloraefolia and F. sonorensis) (Huxman and Monson 2003), but this intermediate is strongly $\mathrm{C}_{3}$-like in many features, including its normal operating intercellular $\mathrm{CO}_{2}$ concentration $\left(C_{\mathrm{i}}\right)$ value and its low $\mathrm{C}_{4}$-cycle activity (Huxman and Monson 2003). Despite these strong physiological and biochemical $\mathrm{C}_{3}$ characteristics, the $\mathrm{C}_{3}-\mathrm{C}_{4}$ intermediate, $F$. floridana, showed improved WUE under the environmental conditions tested in this study as compared to the $\mathrm{C}_{3}$ species. This advantage could be related to the efficiency of $\mathrm{CO}_{2}$ recapture by glycine decarboxylase and consequently reduction of photorespiration, improving 
photosynthetic performance, and WUE, as compared to $\mathrm{C}_{3}$ plants (Monson and Rawsthorne 2002, Dias and Brüggemann 2007).

The $\mathrm{C}_{4}$-like intermediate species, $F$. brownii, showed WUE similar to the $\mathrm{C}_{4}$ plant under well-watered conditions. Under DS, WUE was lower than for the $\mathrm{C}_{4}$ species. However, this species still presents an advantage over the other intermediate species $\left(\mathrm{C}_{3}-\mathrm{C}_{4}\right)$ and $\mathrm{C}_{3}$ plant. $F$. brownii is the most advanced intermediate species in terms of development of the $\mathrm{C}_{4}$ syndrome (Monson and Rawsthorne 2002). The high degree of development of the $\mathrm{C}_{4}$-cycle in this intermediate (Monson and Rawsthorne 2002), associated with an efficient $\mathrm{CO}_{2}$ concentration mechanism in the bundle sheath cells, resulted in high assimilation of $\mathrm{CO}_{2}$, which allows this species to photosynthesize at lower stomatal conductance than in the $\mathrm{C}_{3}$ and $\mathrm{C}_{3}-\mathrm{C}_{4}$ intermediate plants (Dias and Brüggemann 2007). The lower stomatal conductance and transpiration rates lead to higher WUE in the $\mathrm{C}_{4}$-like intermediate $F$. brownii.

Field and laboratory studies in photosynthetically intermediate Flaveria species showed that the ability of several intermediate species to reduce photorespiration is advantageous under high temperature and DS conditions,

\section{References}

Apel, P.: Water use efficiency in Flaveria and Moricandia species. - Biol. Plant. 36: 243-246, 1994.

Beyel, V., Brüggemann, W.: Differential inhibition of photosynthesis during pre-flowering drought stress in Sorghum bicolor genotypes with different senescence traits. - Physiol. Plant. 124: 249-259, 2005.

Brown, R.H., Simmons, R.E.: Photosynthesis of grass species differing in $\mathrm{CO}_{2}$ fixation pathway. 1. Water use efficiency. Crop Sci. 19: 375-379, 1979.

Dias, M.C., Brüggemann, W.: Differential inhibition of photosynthesis under drought stress in Flaveria species with different degrees of development of the $\mathrm{C}_{4}$ syndrome. Photosynthetica 45: 75-84, 2007.

Huxman, T.E., Monson, R.K.: Stomatal response of $\mathrm{C}_{3}, \mathrm{C}_{3}-\mathrm{C}_{4}$ and $\mathrm{C}_{4}$ Flaveria species to light and intercellular $\mathrm{CO}_{2}$ concentration: implications for the evolution of stomatal behaviour. Plant Cell Environ. 26: 313-322, 2003.

Hylton, C.M., Rawsthorne, S., Smith, A.M., Jones, D.A.: Glycine decarboxylase is confined to the bundle-sheath cells of leaves of $\mathrm{C}_{3}-\mathrm{C}_{4}$ intermediate species. - Planta 175: 452459, 1988

Ku, M.S.B., Schmitt, M.R., Edwards, G.E.: Quantitative determination of RuBP carboxylase-oxygenase protein in leaves of several $C_{3}$ and $C_{4}$ plants. - J. Exp. Bot. 30: 89-98, 1979.

$\mathrm{Ku}$, M.S.B., Monson, R.K., Littlejohn, R.O., Nakamoto, H., Fisher, D.B., Edwards, G.E.: Photosynthetic characteristics of $\mathrm{C}_{3}-\mathrm{C}_{4}$ intermediate Flaveria species. 1. Leaf anatomy, photosynthetic responses to $\mathrm{O}_{2}$ and $\mathrm{CO}_{2}$, and activities of key enzymes in the $\mathrm{C}_{3}$ and $\mathrm{C}_{4}$ pathways. - Plant Physiol. 71: 944948, 1983.

Kocacinar, F., McKown, A.D., Sage, T. L., Sage, R. F.: 2008. Photosynthetic pathway influences xylem structure and function in Flaveria (Asteraceae). - Plant Cell Environ. 31: where stomatal closure may limit internal $\mathrm{CO}_{2}$ concentrations ( $\mathrm{Ku}$ et al. 1983, Monson 1989, Monson and Jaeger 1991, Sudderth et al. 2009). Improved WUE was also reported in other $\mathrm{C}_{3}-\mathrm{C}_{4}$ intermediate species from other genera, i.e. Moricandia and Panicum, under well-watered conditions (Hylton et al. 1988) and DS ones (Ku et al. 1979, Brown and Simmons 1979). In our study, we compared WUE in two intermediate Flaveria species with different degrees of $\mathrm{C}_{4}$ development relative to the $\mathrm{C}_{3}$ and $\mathrm{C}_{4}$ species. From the results it can be concluded that under well-watered and DS conditions, $\mathrm{C}_{3}-\mathrm{C}_{4}$ and $\mathrm{C}_{4}$-like $\mathrm{CO}_{2}$ fixation type in Flaveria is connected with an improved WUE in comparison to $\mathrm{a}_{3}$ species.

Although this genus is physiologically, biochemically, and genetically well characterized (Sage 2004, Mckown et al. 2005), further research combining more Flaveria species and other stress factors should be carried out in order to improve our understanding of the environmental conditions that promote the evolution of the $\mathrm{C}_{4}$ photosynthetic pathway. Additionally, field studies will improve and complete our knowledge on the physiological performance of these intermediate species under natural growing conditions.

1363-1376, 2008.

Kutschera, U., Niklas, K.J.: Photosynthesis research on yellowtops: Macroevolution in progress. -Theory Biosci. 125: 81-92, 2007.

McKown, A.D., Moncalvo, J.-M., Dengler, N.G.: Phylogeny of Flaveria (Asteraceae) and inference of $\mathrm{C}_{4}$ photosynthesis evolution. - Amer. J. Bot. 92: 1911-1928, 2005.

Monson, R.K.: The relative contributions of reduced photorespiration, and improved water- use and nitrogen-use efficiencies, to the advantages of $\mathrm{C}_{3}-\mathrm{C}_{4}$ intermediate photosynthesis in Flaveria. - Oecologia 80: 215-221, 1989.

Monson, R.K.: The origins of the $\mathrm{C}_{4}$ genes and evolutionary pattern in the $\mathrm{C}_{4}$ metabolic phenotype. - In: Sage, R.F., Monson, R.K. (ed.): $\mathrm{C}_{4}$ Plant Biology. Pp. 377-410. Academic Press, San Diego 1999.

Monson, R.K., Jaeger, C.H.: Photosynthetic characteristics of $\mathrm{C}_{3}-\mathrm{C}_{4}$ intermediate Flaveria floridana (Asteraceae) in natural habitats: evidence of advantages to $\mathrm{C}_{3}-\mathrm{C}_{4}$ photosynthesis at high leaf temperatures. - Amer. J. Bot. 78: 795-800, 1991.

Monson, R.M., Rawsthorne, S.: $\mathrm{CO}_{2}$ assimilation in $\mathrm{C}_{3}-\mathrm{C}_{4}$ intermediate plants. - In: Leegood, R.C., Sharkey, T.D., von Caemmerer, S.C. (ed.): Photosynthesis: Physiology and Metabolism. Kluwer Academic Press, Dordrecht 2002.

Reed, J.E., Chollet, R.: Immunofluorescent localization of phosphoenolpyruvate carboxylase and ribulose 1,5-bisphosphate carboxylase/oxygenase proteins in leaves of $\mathrm{C}_{3}, \mathrm{C}_{4}$ and $\mathrm{C}_{3}-\mathrm{C}_{4}$ intermediate Flaveria species. - Planta 165: 439-445, 1985.

Sage, R.F.: The evolution of the $\mathrm{C}_{4}$ photosynthesis. - New Phytol. 161: 341-370, 2004.

Scheffer, F., Schachtschnabel, P. (ed.): [Lehrbuch der Bodenkunde.] $15^{\text {th }}$ Ed. - Spektrum A. Verlag, Heidelberg 2002. [In German.] 
Scholander, P.F., Hammel, H.T., Bradstred, E.D., Hemmings, E.A: Sap pressure in vascular plants - negative hydrostatic pressure can be measured in plants. - Science 148: 339-346, 1965.

Sudderth, E.A., Espinosa-García, F. J., Holbrook, N.M.: Geographic distributions and physiological characteristics of co-existing Flaveria species in south-central Mexico. - Flora 204: 89-98, 2009.
Walter, H., Kreeb, K.-H.: [Die Hydratation und Hydratur des Protoplasmas der Pflanzen und ihre ökophysiologische Bedeutung.] - Protoplasmatologia II C6. Springer-Verlag, Wien 1970. [In German.]

Westhoff, P., Gowik, U.: Evolution of $\mathrm{C}_{4}$ phosphoenolpyruvate carboxylase. Genes and proteins: a case study with the genus Flaveria. - Ann. Bot. 93: 13-23, 2004. 